\title{
Evaluation of the Relationship between Organizational Justice and Job Satisfaction among Employees of Five Selected Manufacturing Firms in South East, Nigeria
}

\author{
Ede Titus Eguji, Ph.D ${ }^{1 *}$, Mbah Paulinus Chigozie, Ph.D ${ }^{2}$ \\ ${ }^{1}$ Department of Sociology and Anthropology, Faculty of Social Sciences, Enugu State University of Science and Technology, Enugu, Enugu State, \\ Nigeria \\ ${ }^{2}$ Department of Business Administration, Faculty of Management Sciences, Enugu State University of Science and Technology, Enugu, Enugu State, \\ Nigeria
}

DOI: $10.36348 /$ sjhss.2020.v05i08.001

| Received: 14.05.2020 | Accepted: 21.05.2020 | Published: 11.08.2020

*Corresponding author: Ede Titus Eguji

\section{Abstract}

This study is an evaluation of the relationship between organizational justice and job satisfaction among employees of five selected manufacturing firms in south east, Nigeria. The population for the study was five thousand, and eleven employees (5,011). The study sample size was eight hundred and ninety-five (895) respondents. Questionnaire which was validated by experts was the instrument used for data collection. Some of the major findings is that there is a positive relationship between promotion and employee commitment in the five selected manufacturing firms in South-East, Nigeria $(\mathrm{r}=.875 ; \mathrm{p}=.000>0.05, \mathrm{n}=895)$; there is a positive relationship between regular payment of salary and employees Productivity in the five selected manufacturing firms in South-East, Nigeria $(r=.745 ; \mathrm{p}=.000>0.05, \mathrm{n}=895)$. The study concluded that there is a positive relationship between promotion and employee commitment, regular payment of salary and employee productivity in selected bakeries in South-East, Nigeria. Given the nature of the industry work environment, ensuring justice or fairness in bakery industries may be an incentive system. Consequent upon the findings, some recommendations were made; Job promotion is an important element that influences employee commitment. It is recommended that manufacturing organizations should emphasize more on job promotion to enhance higher employee commitment that will engender high productivity. It is also recommended that the salary and remuneration packages of the industry should be competitive with other sectors which makes them recruit and source qualified and skilled employees.

Keywords: Organizational Justice; Job Satisfaction and Manufacturing Firms.

Copyright @ 2020: This is an open-access article distributed under the terms of the Creative Commons Attribution license which permits unrestricted use, distribution, and reproduction in any medium for non-commercial use (NonCommercial, or CC-BY-NC) provided the original author and source are credited.

\section{INTRODUCTION}

The notion of justice has become an increasingly important construct in behaviour and management over the last two decades because of its serious personal and organizational consequences [1]. People are social beings and devote a considerable amount of time to their workplace. Thus, organizations create surroundings in which employees can interact socially. One concept that is fundamental to human social interaction is justice. Whether it is a promotion decision, the assignment of tasks, the allocation of rewards or simply any other type of social exchange, issues of fairness are bounding to arise. Organizational justice refers to fairness and ethical behaviour within an organization. Organizational justice is defined as personal sense from fair wages and benefits.
Organizational Justice emphasizes manager decision, perceived equality, effects of justice, and the relationship between individual and environmental and describes individuals' perceptions of fairness in organizations [2]. In other words, the term organizational justice refers to the extent to which employees are treated fairly at their workplace. The principles of justice have long been recognized by social scientists as crucial for the functioning of organizations and the personal satisfaction of individuals employed.

Justice or fairness refers to the idea that an action or decision is morally right, which may be defined according to ethics, religion, fairness, equity, or the law. People are naturally attentive to the justice of events and situations in their everyday lives, across a 
variety of contexts. Individuals react to actions and decisions made by organizations every day. An individual's perceptions of these decisions as fair or unfair can influence the individual's subsequent attitudes and behaviours. Fairness is often of central interest to organizations because the implications of perceptions of injustice can impact negative job attitudes and behaviours at work. Justice in organizations can include issues related to perceptions of fair pay, equal opportunities for promotion, and personnel selection procedures [3]. Organizational justice is also seen as an employees' evaluation toward the organization's treatment in an effort to get results, whether the process to get results is also made fairly or not, as well as other forms of interpersonal treatment on each employee. It is a reality that assets do everything possible but the fact cannot be denied that it is the employees who make things possible in the organization. Employees are the most valuable assets of any organization whether it is a profitable or nonprofitable organization. Today the main issue for competitive organizations is the retaining of its valued employees. It is generally in an organization's best interest to consume its energy to retain high-quality employees [4]. The existence of organizational justice is a critical issue for the success of an organization. It has a direct link with the performance of its employees. Organizational Justice has been seen as an important variable that plays a major role in improving the performance of employees of an organization.

\section{Statement of the Problem}

The existence of organizational justice is a critical issue for the success of an organization. In Nigeria, manufacturing firms are facing extraordinary challenges and competitive pressures such as the problem of manager decision, perceived inequality, injustice, and the poor relationship between individual and environment, poor line of communication and commitment to work, no access to training and career advancement, poor remuneration, unfairness to decisions made in the organizations, financial challenges, lack of job security and quality. The overall achievement of organizational goals and satisfaction of every employee counts irrespective of their type of job and individual designations. Organizations need to develop such a system where a conducive environment is provided to their employees within the existing resources to get better employee performance.

\section{Objectives of the Study}

The main objective of the study was to evaluate organizational justice and job satisfaction among employees of five selected manufacturing firms in South East, Nigeria. The specific objectives are:

1. To examine the relationship between promotion and employees' commitment to work in five selected manufacturing firms in South-East, Nigeria.
2. To determine the relationship between regular payment of salary and employee productivity in five selected manufacturing firms in SouthEast, Nigeria.

\section{Research Questions}

The following research questions have been formulated to guide the study.

1. What is the relationship between promotion and employees' commitment to work in five selected manufacturing firms in South-East, Nigeria?

2. What is the relationship between regular payment of salary and employee productivity in five selected manufacturing firms in SouthEast, Nigeria?

\section{LITERATURE REVIEW \\ Conceptual Framework \\ Organizational Justice}

Organizational justice' refers to the extent to which employees perceive workplace procedures, interactions and outcomes to be fair in nature. These perceptions can influence attitudes and behaviour for good or ill, in turn having a positive or negative impact on employee performance and the organization's success [5]. Organizational justice with regard to how an employee judges the behaviour of the organization and the employee's resulting attitude and behavior, for example, if a firm makes redundant half of the workers, an employee may feel a sense of injustice with a resulting change in attitude and a drop in productivity. Justice or fairness refers to the idea that an action or decision is morally right, which may be defined according to ethics, religion, fairness, equity, or the law. People are naturally attentive to the justice of events and situations in their everyday lives, across a variety of contexts. Individuals react to actions and decisions made by organizations every day. An individual's perceptions of these decisions as fair or unfair can influence the individual's subsequent attitudes and behaviors. Fairness is often of central interest to organizations because the implications of perceptions of injustice can impact job attitudes and behaviors at work. Justice in organizations can include issues related to perceptions of fair pay, equal opportunities for promotion, and personnel selection procedures [3].

Often the notion of organizational justice will only become relevant and tangible when a violation of said justice occurs. Examples of perceived injustices within an organization might include unequal pay for men and women doing the same job, performance reviews being conducted by someone with whom the employee has had little previous contact, the use of personality inventories to select new staff, arbitrary dismissals. 


\section{Job Satisfaction}

Job satisfaction is an employee's subjective feeling of happiness or contentment in his or her work situation, usually dependent on working conditions, compensation, and opportunities for accomplishment and advancement [6]. It is the feeling of contentment or a sense of accomplishment, which an employee derives from his/her job. It is a result of appraisal that causes people to attain their job values or meet out their basic needs. It helps in determining, to what extent a person likes or dislikes his/her job. Hulin and Judge [7] have noted that job satisfaction includes multidimensional psychological responses to an individual's job and that these personal responses have cognitive (evaluative), affective (or emotional), and behavioural components. Job satisfaction scales vary in the extent to which they assess the affective feelings about the job or the cognitive assessment of the job Affective job satisfaction is a subjective construct representing an emotional feeling individuals have about their job. Hence, effective job satisfaction for individuals reflects the degree of pleasure or happiness their job in general induces. Cognitive job satisfaction is a more objective and logical evaluation of various facets of a job [7].

\section{Employee Promotion}

The promotion has its roots in the Latin word 'Promovere' which means 'to move forward'. Its dictionary meaning also is almost the same e.g. to elevate, to advance, to contribute to the growth or prosperity of somebody, etc. Really speaking, promotion refers to advancement in rank and status leading to the enhancement of emoluments. Promotion is the transfer of an employee to a job that pays more money or one that carries some preferred status [8]. Promotion is the advancement of an employee to a better job-better in terms of greater responsibilities, more prestige or status, greater skill and especially, increased rate of pay or salary. Promotion means elevation to a higher job accompanied by increased pay and privileges. It is an upward advancement of an employee in an organization, which commands better pay, better status, higher opportunities, higher responsibilities, and a better working environment. The promotion provides motivation and job satisfaction to all personnel. Quite often, industrial unrest, frustration and negative feelings among the employees are on account of matters concerned with promotion. Sound promotion policy is essential in all types of organizations. It is purely a managerial decision in which trade unions have no role to play [9].

\section{Employee Commitment}

Employee Commitment is a psychological state that binds an individual to the organization. It refers to the likelihood that an individual will stick to the organization, feel psychologically attached to it, whether the job is satisfying or not. Companies often mistake employee retention for Commitment. It would be wrong to say that an employee who stays with the company is committed. The various forms of commitment coexist simultaneously, yet are distinguishable from each other [10]. Not all employees are committed and certainly are not at the same level of commitment. Plus, "commitment" can mean different things to different workers. Overall, it's the bond employees have with their place of work. When they are committed, they feel like they fit in and know (and align with) the values of the organization. Committed employees are an asset to an organization and add value in more ways than one. They are supportive and more productive than non-committed employees. These employees do not easily utilize their sick days and are more prone to adopting the vision of the organization if it's not already aligned with their own value system. Much like any relationship, commitment is at the heart of a healthy partnership. When employees are committed to their work and place of business, they are more likely to be happy and productive. Committed employees take ownership of their work and are ambassadors for their company, both inside and outside of office doors. They are less likely to job hunt, be tempted by recruiters who seek out passive candidates and are most likely to pursue advancements and promotions [11].

\section{Regular Payment of Salary}

A salary is a form of payment from an employer to an employee which may be specified in an employment contract [12]. It is contrasted with piece wages, where each job, hour or other unit is paid separately, rather than on a periodic basis. From the point of view of running a business, the salary can also be viewed as the cost of acquiring and retaining human resources for running operations and is then termed personnel expense or salary expense. In accounting, salaries are recorded in payroll accounts. Salary is a fixed amount of money or compensation paid to an employee by an employer in return for work performed. Salary is commonly paid in fixed intervals, for example, monthly payments of one-twelfth of the annual salary. Salary is typically determined by comparing market pay rates for people performing similar work in similar industries in the same region. Salary is also determined by levelling the pay rates and salary ranges established by an individual employer. Salary is also affected by the number of people available to perform a specific job in the employer's employment locale. Salaries are fixed cost in nature. A salaried employee (also known as a salaried employee) is a worker who is paid a fixed amount of money or compensation, also known as a salary by an employer [12].

A salary is a regular payment by an employer to an employee for employment that is expressed either monthly or annually but is paid most commonly on a monthly basis, especially to white-collar workers, managers, directors, and professionals. A salaried employee or salaried employee is paid a fixed amount of money each month. Their earnings are typically 
supplemented with paid vacations and public holidays, healthcare insurance in country's without universal coverage, and other benefits. Salaries are usually determined by comparing what other people in similar positions are paid in the same region and industry. Most large employers have levels of pay rates and salary ranges which are linked to hierarchy and time served. In most countries, salaries are also affected by supply and demand how many job vacancies there are for a specific position in relation to the number of people that exist in the area who could fill that post [12].

Regular payment of salary is usually in the form of reward, bonuses, profit-sharing plans, and pension plans. Thus, these include redundancy, retirement benefits, and employees' stock ownership plans. Other incentive systems facilitate employee's effective discharge of their responsibilities of actualizing the goals of the organization [13]. In other words, the reward systems available to the employee's profession go a long way to determine how they perform their job. Incentive system in any organization is a means of sustaining those workers on the job. However, it is a motivating factor that influences the attitude of the worker on the job [14]. Regular salary and other financial incentives, of no doubt, undermine the ability to motivate teachers towards their positive job disposition, positive job attitude, greater productivity, higher commitment, and positive employees' achievement [15]. Most importantly, regular salary and fringe benefits help organizations to focus more attention on their primary work role, become independent, adequately cater to their family members, meet other needs and values in life, and increase their self-perception and status in the society [16].

\section{Employee Productivity}

Productivity is the driving force behind a company's growth and profitability. Productivity is a measurement or calculation between inputs and outputs. Inputs include raw materials, machinery, and labour; outputs are the goods or services produced. If the outputs are equivalent to the inputs, the worker is considered productive. If the same number of workers starts to produce more goods services than in a prior period, perhaps as the result in a change in working conditions, then productivity has increased. Productivity is linked to employee morale. When employees are happy at work they have more motivation, which increases productivity. Poor morale causes employees to be disengaged. If employees are not given the proper resources to do their jobs easily and efficiently, their productivity will suffer. Low productivity can be boosted in a number of ways. Some managers might install monitoring software that tracks what employees do all day long to try to eliminate wasted employee hours, while others will try to boost employee morale or training or invest in labor-saving devices [17]. Productivity directly affects a company's profit. When employees are productive they accomplish more in a given amount of time. In turn, their efficiency saves their company money in time and labour. When employees are unproductive, they take longer to complete projects, which cost employers more money due to the lost time [17].

Employee productivity is the evaluation of an employee's efficiency. The evaluation may be done in terms of the specific output of an employee in a specific time period and is calculated against the average of other employees that are completing the same tasks. As the success of the organization depends on the workforce's productivity, employee productivity is paramount for enterprises. When looking at improving the employee productivity rates, organizations being to incorporate collaboration solutions into their daily workflows. The vast availability of mobile collaboration tools allows for much greater productivity, regardless of geographic location. Employee recognition often equates to greater productivity, even simple acknowledgments of their work by co-workers increases productivity. Recognizing the most productive employees is important as it will also drive co-workers to be productive themselves. This can be achieved in many ways, through compensation, or employee-of-the-month titles. That being said, increasing compensation does not always relate to an increase in employee productivity. The constant connectivity that comes with social networking, on the other hand, has detrimental effects on employee productivity rates. To curb the issue, many organizations monitor employee access to websites when working on the corporate network. Another negative impact is the processing of emails. The ineffective handling of emails in the workplace takes up a significant amount of an employee's time. To combat this issue, many organizations are today limiting the number of email processing sessions on a daily basis or limiting the accessibility of emails from the corporate network to certain hours of the day [17].

\section{The Relationship between Promotion and Employee Commitment to Work}

Azman [18], examined an empirical study on the relationship between transformational leadership, empowerment and organizational commitment in the firm in East Malaysia. The study adopted a Stepwise Regression analysis. The study shows that there is a relationship between empowerment and transformational leadership positively and significantly correlated with organizational commitment. The study concludes that empowerment acts as a mediating variable in the relationship between transformational leadership and organizational commitment in the organizational sample. The study recommended that an organization should adopt a transformational leadership style for the effects of the system. 
Abbas and Asri [19], conducted a study on the relationship between effective organizational communication and the performance of central office staff. The study presented an empirical study to measure the role of inter-organizational communication on efficiency among administration employees who work for one of the oldest banks in Iran, Bank Melli Iran. Inter-organizational communication plays an important role in promoting strategic collaboration among firms. It can improve productivity and increases collaboration among employees. The study used 380 full-time employees who work for 28 different administration divisions of this bank. The survey used a questionnaire consists of 19 questions about interorganizational communication and 25 questions about the efficiency of employees. The result of the survey confirms there is a meaningful relationship between inter-organizational communication and the efficiency of all administration employees who work for this bank. There is also a meaningful relationship between age and efficiency and the maximum efficiency belongs to people aged 31 to 40 . Based on the survey, men have more inter-organizational efficiency than women do. The result of the survey also confirms that positivism impacts more than other factors on efficiency. Among the five effective factors, empathy has the most impact and responsiveness to 6 efficiency dimensions.

Chung-Chieh and Chih-Jen [20], examined the relationship between employee commitment and job attitude and its effect on service quality in the tourism industry. The main aim of the study was to analyze the relationship between employee commitment and job attitude in the tourism industry and its effect on service quality. The study found that the biographical characteristics of the employees have an effect on job attitude and job commitment. In order to enhance job satisfaction, employees need to be motivated in a relevant manner.

\section{Regular Payment of Salary and Employee Productivity}

Ademola [21] conducted a study on the effect of organizational justice and organizational environment on the turn-over intention of organizational workers in Ekiti State, Nigeria. The study investigated the effect of organizational justice and organizational environment on the turn-over intention of workers in Ekiti State, Nigeria. A total of two hundred respondents were used for the study. The study adopted the Psychological Needs Scale (BPNS) developed by Deci and Ryon [22] while the turnover intention was measure using the Turnover Intention Scale developed by Fichman, Jenkins, and Klesh [23]. The results revealed that organizational justice has a significant effect on turnover intention while the organizational environment has no significant effect on turnover intention. The study concludes that it is a common knowledge in Nigeria that nurses feel deprived, cheated and marginalized by not been treated equally as the medical doctors. The study recommends that employees work should be deeply affected by government and management to deliver quality service at a lower cost and that the radical changes in the organizational environment may result in mounting frustration among employees.

Wakil [24] conducted a study on the survey of pay satisfaction, job satisfaction and employee turnover in selected business organisations in Lagos, Nigeria. The study was to Ascertaining the level of association between Pay Satisfaction and Job satisfaction among workers in Lagos. The study made use of the Pay Satisfaction Scale (PSS), the Minnesota Satisfaction Questionnaire (MSQ) and Turnover Intention Questionnaire (TIQ) as measures in the study. The data obtained were analyzed using Correlation Analysis and Regression Analysis. The results of the analysis indicated that the relationship between pay satisfaction and employee turnover intention was positive, this was the expected direction. The study concludes that there is a great effect on pay satisfaction and job satisfaction. The study recommended that pay satisfaction and job satisfaction could jointly predict employee turnover.

\section{RESEARCH METHODOLOGY Research Design}

This study employed a longitudinal survey research design since it involves the examination of a phenomenon without any attempt to manipulate the study variables and is characterized by the selection of random samples from the population to obtain empirical knowledge of contemporary nature.

\section{Area of the Study}

The area of the present study was selected using manufacturing firms in South-Eastern, Nigeria; South East of Nigeria is one of the six geopolitical zones in the country.

The five selected manufacturing firms in South-Eastern, Nigeria include:

Enugu State: Chitis Ltd (1A Ezillo Street, Independence Layout, Enugu)

Ebonyi State: Vegas Bakery Limited is located at 79 Ogoja Road Abakaliki Ebonyi State.

Anambra State: Amerigo Bakery is located at \#4 Agulu Road Amawbia Awka South, Anambra.

Imo State: All Tea-Mate Gold Bakery is a reputable pastry company situated within Umuguma, Owerri Capital Territory in Imo State Nigeria.

Abia State: M.O. NNAJI Bread No. 56 Obohia Road, Aba, Abia State. Nigeria.

\section{Population of the Study}

The population of an understudy is shown 
Table-1: Population Distribution

\begin{tabular}{|l|l|l|l|l|l|}
\hline S/N & Manufacturing firms & Mgt & Senior & Junior & Total \\
\hline 1 & Chitis Ltd Enugu state & 43 & 353 & 534 & 930 \\
\hline 2 & All Tea-Mate Gold Bakery Imo state & 58 & 322 & 602 & 982 \\
\hline 3 & AMERIGO bakeries Anambra state & 41 & 425 & 694 & 1160 \\
\hline 4 & M.O. Nnaji Bakery Abia state & 28 & 215 & 732 & 975 \\
\hline 5 & Vegas Bakery Limited Ebonyi & 38 & 347 & 579 & 964 \\
\hline & Total & $\mathbf{2 0 8}$ & $\mathbf{1 6 6 2}$ & $\mathbf{3 1 4 1}$ & $\mathbf{5 0 1 1}$ \\
\hline
\end{tabular}

Source: Administrative Officers, 2018.

Table-1 above shows that five firms were selected from five states in Southeast Nigeria, which is made up of management, senior and junior staff of the bakery firms which gave a total population of five thousand, and eleven employees $(5,011)$.

\section{Sampling Technique/ Sample size determination}

To determine the sample for the study, the random sampling technique was applied since the population used is a homogenous one. On the basis of this, the population was random into firms registered with MAN and those not registered but has a capital investment of more than N10milion. The study sample size was eight hundred and ninety-five (895) respondents. This sample size is justified because the population was huge and such a sample was sufficient to address the research problem. The actual population was five thousand, eleven employees $(5,011)$ employees. The population of the study was drawn from the three levels of employees in these organizations under study using a simple random sampling method. To determine the adequate sample size, the researcher opts for the Freund and William's statistical formula. In calculating the sample size, the researcher used the statistical formula for selecting a finite population as formulated by Freund and Williams.

$$
n=\frac{Z^{2} N(p q)}{N(e)^{e}+Z^{2}(p q)}
$$

Where,

$$
\begin{aligned}
& \mathrm{n}=\text { Sample Size } \\
& \mathrm{N}=\text { The population } \\
& \mathrm{p}=\text { Probability of success/proportion } \\
& \mathrm{q}=\text { Probability of failure/proportion } \\
& \mathrm{Z}=\text { Standard error of the mean } \\
& \mathrm{e}=\text { Limit of tolerable error (or level of } \\
& \text { significance) } \\
& \mathrm{N}=5,011 \\
& \mathrm{p}=.5 \\
& \mathrm{q}=(1-.5)=.5 \\
& \mathrm{Z}=97 \text { percent }=1.98 \\
& \mathrm{e}=0.3 \text { percent }
\end{aligned}
$$

$$
\begin{aligned}
& \frac{(1.98)^{2} \times 5011 \times .5 \times .5}{5011(0.03)^{2}+(1.98)^{2} \times .5 \times .5} \\
& \frac{4911.811}{4.5099+.9801} \\
& \frac{4911.811}{4.49}
\end{aligned}
$$

$$
\begin{aligned}
& =894.68 \\
& \simeq 895
\end{aligned}
$$

\section{Instruments for Data Collection}

The main instrument for data collection is a structured questionnaire and in-depth interview (IDI) as a means to explain more from the questionnaire. Data were collected between $25^{\text {th }}$ May- $26^{\text {th }}$ June 2019. Copies of the questionnaire were administered to management, senior and junior of the organizations studied. The questionnaire was divided into two sections, section A is designed to gather information about the participant characteristics like gender, demographic information, qualification, age, and work experience. While section $\mathrm{B}$ is designed to gather responses of employees on the extent the independent variable affects the dependent variable. The responses generated would be used thereafter for data analysis.

\section{Validity and Reliability of the Instrument}

The face and content validity of the instrument was used by giving out copies of the questionnaire to some experts in research in the Department of Sociology and Anthropology, and they reviewed the contents items of the questionnaire, in-depth interview (IDI) for clarity of words, contents coverage, relevance and effectiveness in measuring the variables under study. To ascertain that the instrument is reliable, the test method was adopted in which 20 copies of the questionnaire were distributed to other firms outside the study; two copies to each firm. These were collected afterward and redistributed after two weeks. The reliability of the two responses was determined using the Spearman rank-order correlation coefficient.

\section{Method of Data Collection}

The questionnaire which constituted part of the instrument for data collection was distributed to the respondents with the aid of five research assistants each for the selected manufacturing firm who were properly tutored on the objectives of the study and their expected roles. The questionnaire was administered during working hours. The researcher gave a 5-day interval before the questionnaire was collected for vetting and analysis. A total of 895 copies of the questionnaire were administered. The corrected completed ones were rated reliable and used for the analysis in this study. 
Method of Data Presentation and Analysis

The questionnaire responses were cleaned, grouped into various categories and entered into the SPSS version 20 software to facilitate analysis using descriptive statistics. Frequency distribution tables were used to summarize the data from the respondents. The analyzed data were presented in frequency distributions table and bar charts for ease of understanding and analysis. Data from the questionnaire were analyzed using simple percentages, mean and standard deviation. The data were expressed in scale. Data were presented in tables, percentages, mean and standard deviation.

Pearson Product-Moment Correlation, Fstatistics, and regression analysis were used to test the hypotheses, determine the nature, and strength of the research variables.
Pearson Product-Moment Correlation

$$
\mathrm{r}=\frac{N \sum X Y-\left(\sum Y\right)}{\sqrt{\left[N \sum X^{2}-\left(\sum X\right)^{2}\left[\sum X Y^{2}-\left(\sum Y\right)^{2}\right]\right.}}
$$

Where

$$
\begin{aligned}
& \mathrm{r}=\text { correlation coefficient } \\
& \mathrm{n}=\text { Sample size } \\
& \mathrm{X}=\text { Variable } \mathrm{X} \text { response } \\
& \mathrm{Y}=\text { Variable } \mathrm{X} \text { response }
\end{aligned}
$$

\section{Data Analysis, Presentation and Interpretation Analyses of Research Questions \\ Research Question 1: What is the relationship between promotion and employee commitment in selected manufacturing firms in South-East, Nigeria?}

Table-2: Response on the statement the extent status leading to enhancement of emolument in the organization increases the employee morale to do more

\begin{tabular}{|l|l|l|l|l|}
\hline & Frequency & Percent & $\operatorname{Mean}(\boldsymbol{\chi})$ & Std. \\
\hline Very great extent & 600 & 73.2 & 3.98 & .199 \\
\hline Little extent & 156 & 19.0 & 3.00 & .425 \\
\hline Nothing at all & 32 & 3.9 & 3.25 & .568 \\
\hline I don't know & 32 & 3.9 & 1.38 & .492 \\
\hline Total & $\mathbf{8 0 1}$ & $\mathbf{1 0 0 . 0}$ & $\mathbf{3 . 6 0}$ & $\mathbf{. 6 7 3}$ \\
\hline
\end{tabular}

Source: Field Survey, 2020

Table-2, indicated that 600 respondents out of 801 representing 73.2 percent were of the opinion to a very great extent that status leading to enhancement of emolument in the organization increases the employee morale to do more with a mean score of (3.98) and standard deviation of (.199). 156 respondents representing 19.0 percent with mean score of (3.00) and standard deviation of (.425) to little extent, 32 were of the opinion nothing at all representing 3.9 percent with mean score of (3.25) and standard deviation of (.568) that status leading to enhancement of emolument in the organization increases the employee morale to do more,
32 respondents representing 3.9 percent with mean score of (1.38) and standard deviation of (.492) with I don't know. The implication of this finding is that status enhancement has much to do in the promotion of employee hard work. In order to get work done, and done right, the leader needs to give employees the support and the training they need. Then employees will stay motivated and do more.

Research Question 2: What is the relationship between regular payment of salary and employee productivity in selected manufacturing firms in South-East, Nigeria?

Table-3: Response on the statement on the extent of improvement of salary in my organisation increases the output

\begin{tabular}{|l|l|l|l|l|}
\hline & Frequency & Percent & Mean $(\boldsymbol{\chi})^{-}$ & Std. \\
\hline Very great extent & 600 & 73.2 & 3.98 & .199 \\
\hline Great extent & 156 & 19.0 & 3.00 & .425 \\
\hline No extent & 32 & 3.9 & 3.25 & .568 \\
\hline I don't know & 32 & 3.9 & 1.38 & .492 \\
\hline Total & $\mathbf{8 0 1}$ & $\mathbf{1 0 0 . 0}$ & $\mathbf{3 . 6 6}$ & $\mathbf{. 6 7 3}$ \\
\hline
\end{tabular}

Source: Field Survey, 2020

Table- 3 indicated that 600 respondents out of 801 representing 73.2 percent were of the opinion to a very great extent that improvement of salary in the organisation increases the output with a mean score of (3.98) and standard deviation of (.199). 156 respondents representing 19.0 percent with mean score of (3.00) and standard deviation of (.425) to great extent, 32 were of the opinion to no extent representing 3.9 percent with mean score of (3.25) and standard deviation of (.568) that improvement of salary in the organisation increases the output, 32 respondents representing 3.9 percent with mean score of (1.38) and standard deviation of (.492) with I don't know. The implication of this finding is that improvement of salary in my organisation increases the output to a very great extent. This is not surprising as salary also plays a distinctive role in how well employees perform. 
Test of Hypotheses

Hypothesis One

$\mathrm{H}_{0}$ : There is no positive relationship between promotion and employee commitment in the selected manufacturing firms in South-East, Nigeria.
$\mathrm{H}_{1}$ : There is a positive relationship between promotion and employee commitment in the selected manufacturing firms in South-East, Nigeria.

\begin{tabular}{|l|l|l|l|l|}
\hline \multicolumn{4}{|l|}{ Model Summary } \\
\hline Model & R & R Square & Adjusted R Square & Std. Error of the Estimate \\
\hline 1 & $.887^{\text {a }}$ & .875 & .875 & .10734 \\
\hline \multicolumn{7}{|l}{ a. Predictors: (Constant), ADV,STA,TRA,INC,EXT } \\
\hline
\end{tabular}

\begin{tabular}{|c|c|c|c|c|c|c|}
\hline \multicolumn{7}{|c|}{ ANOVA } \\
\hline \multicolumn{2}{|c|}{ Model } & Sum of Squares & Df & Mean Square & $\mathrm{F}$ & Sig. \\
\hline \multirow[t]{3}{*}{1} & Regression & 362.364 & 3 & 120.788 & 104.821 & $.000^{\mathrm{b}}$ \\
\hline & Residual & 9.402 & 816 & .012 & & \\
\hline & Total & 371.766 & 819 & & & \\
\hline \multicolumn{7}{|c|}{ a. Dependent Variable: PROMO } \\
\hline \multicolumn{7}{|c|}{ b. Predictors: (Constant), ADV,STA,TRA,INC,EXT } \\
\hline
\end{tabular}

Where:

PROM = The relationship between promotion and employee commitment in five selected manufacturing firms in South-East, Nigeria. $\mathrm{ADV}=$ Advancement in rank in the organization makes the employee to work harder

STA $=$ The extent status leading to enhancement of emolument in your organization increases the employee morale to do more

TRA $=$ The transfer of an employee to a job that pays more in the organization empowers the employees.

INC $=$ The increase in greater responsibilities with additional payment makes the employees put more effort into their duties.

$\mathrm{EXT}=$ The extent advancement of the employee to a greater skill promotes goodwill to your organization

Level of significance: $\alpha$ at 5percent

Degree of freedom: $\frac{N-1}{K-N}=\frac{5-1}{895-5}=(890,4)=2.7858$

$\mathrm{F}$ - tabulated value $=2.7858$

\section{Decision Rule}

If the f-calculated is greater than the $\mathrm{f}$ tabulated $\{\mathrm{F}$-cal $>$ F-tab $\}$ reject the null hypothesis $\left\{\mathrm{H}_{0}\right\}$ that the overall estimate is not significant and if otherwise conclude that the overall estimate is statistically significant.

\section{Decision}

Statistical Criteria \{First Order Test $\}$

\section{Coefficient of Multiple Determinants $\left\{\mathbf{R}^{2}\right\}$}

The $\mathrm{R}^{2} \quad\{\mathrm{R}$-Squared $\}$ which measures the overall goodness of fit of the entire regression, shows the value as .875 and adjusted to .875 . This means that $\mathrm{R}^{2}$ suggests that Promotion variables accounted for 87.5 percent approximately 88 percent of the variation of the employee's commitment to the manufacturing firms. This indicated that the independent variables explained about 89 percent of the variation in the dependent variable. It showed the goodness of fit. We then concluded from the analysis that there is a positive relationship between promotion and employee commitment in the selected manufacturing firms in South-East, Nigeria.

From the result, F-calculated $\{104.821\}$ is greater than the F-tabulated $\{2.7858\}$, that is, Fcal $>$ Ftab. Hence, we reject the null hypothesis $\left\{\mathrm{H}_{0}\right\}$ and accept the Alternative hypothesis which means that the overall estimate has a good fit which also implies that our independent variables are simultaneously significant. We now conclude from the analysis that there is a positive relationship between promotion and employee commitment in the five selected manufacturing firms in South-East, Nigeria.

\section{Hypothesis Two}

$\mathrm{H}_{0}$ : There is no positive relationship between regular payment of salary and employee productivity in five selected manufacturing firms in South-East, Nigeria. $\mathrm{H}_{2}$ : There is a positive relationship between regular payment of salary and employee productivity in five selected manufacturing firms in South-East, Nigeria. 


\begin{tabular}{|l|l|l|l|l|}
\hline \multicolumn{4}{|c|}{ Model Summary } \\
\hline Model & R & R Square & Adjusted R Square & Std. Error of the Estimate \\
\hline 1 & $.704^{\mathrm{a}}$ & .747 & .745 & .33483 \\
\hline a. Predictors: (Constant), IMP, STA, WOF, VOL, REM \\
\hline
\end{tabular}

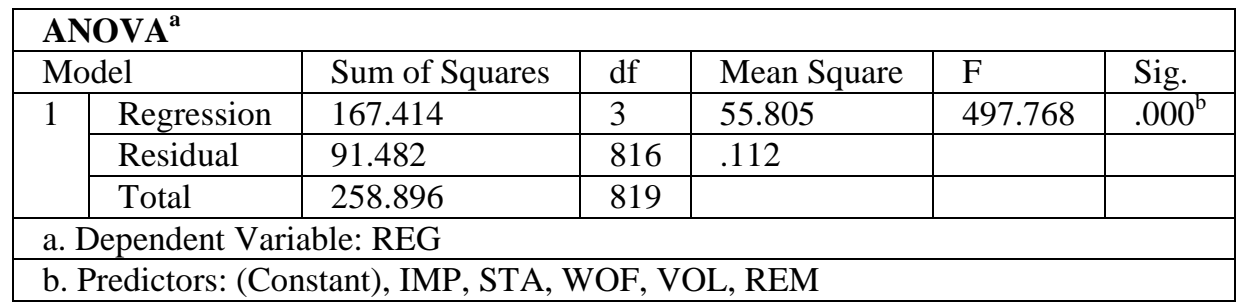

Where,

REG = The relationship between regular payment of salary and employee productivity in five selected manufacturing firms in SouthEast, Nigeria.

IMP = The extent of improvement of salary in the organization increases the output.

STA = Staff salary results in retention of employees in the organization.

$\mathrm{WOF}=$ How an increase in staff morale improves hard work in the organization.

$\mathrm{VOL}=$ How rare voluntary resignation in the organization due to work environment.

REM = Remuneration in the organization that ensures organizational attachment

Level of significance: $\alpha$ at 5 percent

Degree of freedom: $\frac{N-1}{K-N}=\frac{5-1}{895-5}=(890,4)=2.7858$

$\mathrm{F}$ - tabulated value $=2.7858$

\section{Decision Rule}

If the f-calculated is greater than the $\mathrm{f}$ tabulated $\{\mathrm{F}$-cal $>$ F-tab $\}$ reject the null hypothesis $\left\{\mathrm{H}_{0}\right\}$ that the overall estimate is not significant and if otherwise conclude that the overall estimate is statistically significant.

\section{DECISION}

\section{Statistical Criteria \{First Order Test}

Coefficient of Multiple Determinants $\left\{\mathbf{R}^{2}\right\}$

The $\mathrm{R}^{2} \quad\{\mathrm{R}$-Squared $\}$ which measures the overall goodness of fit of the entire regression, shows the value as .747 and adjusted to .745 . This means that $\mathrm{R}^{2}$ suggests that regular payment of salary variables accounted for 74.5 percent approximately 75 percent of the variation of the employee's productivity. This indicated that the independent variables explained about 89 percent of the variation in the dependent variable. It showed the goodness of fit. We then concluded from the analysis that there is a positive relationship between regular payment of salary and employee productivity in five selected manufacturing firms in South-East, Nigeria.

From the result, F-calculated $\{497.768\}$ is greater than the F-tabulated $\{2.7858\}$, that is, Fcal $>$ Ftab. Hence, we reject the null hypothesis $\left\{\mathrm{H}_{0}\right\}$ and accept the Alternative hypothesis which means that the overall estimate has a good fit which also implies that our independent variables are simultaneously significant. We now concluded from the analysis that there is a positive relationship between regular payment of salary and employee productivity in five selected manufacturing firms in South-East, Nigeria.

\section{Summary of Findings}

1. There is a positive relationship between promotion and employee commitment in the five selected manufacturing firms in SouthEast, Nigeria $(r=.875 ; \mathrm{p}=.000>0.05, \mathrm{n}=895)$.

2. There is a positive relationship between regular payment of salary and employees Productivity in the five selected manufacturing firms in South-East, Nigeria $(\mathrm{r}=.745 ; \mathrm{p}=$ $.000>0.05, \mathrm{n}=895)$.

\section{CONCLUSION}

It was observed that there is a positive relationship between promotion and employee commitment, regular payment of salary and employee productivity in selected bakeries in South-East, Nigeria. Given the nature of the industry work environment, ensuring justice or fairness in bakery industries may be an incentive system. This could be in the form of a promotion, regular payment of salary, and so on. Whatever the incentive, it is important that employees understand what the rewards are for and how they are allocated. On the other hand, many employees in the bakery industry are underemployed. If employees are encouraged to become more productive, to learn new skills, and to take more responsibility, employee turnover could be reduced, and could also improve employee morale and job satisfaction.

\section{RECOMMENDATIONS}

Based on the findings in the study, the researcher considered the following recommendations desirable.

1. Job promotion is an important element that influences employee commitment. It is recommended that manufacturing organizations should emphasize more on job promotion to 
enhance higher employee commitment that will engender high productivity. This is because employee commitment is vital to the productivity, quality and good performance of an organisation.

2. It is also recommended that the salary and remuneration packages of the industry should be competitive with other sectors which makes them recruit and source qualified and skilled employees.

\section{REFERENCES}

1. Cohen-Charash, Y., \& Spector, P. E. (2001). The role of justice in organization: a meta-analysis. Organizational Behaviour and Human Decision Processes, 8(6):278-321.

2. Souad, D., Ilyes, S., \& Kamel, B. (2017). The Impact of Organizational Justice On Organizational Citizenship. International Journal of Management. 8(3):169-179.

3. Tabibnia, S. \& Lieberman, E. (2008). Organizatio nal justice. Retrieved from https://en.wikipedia.org /wiki/Organizational_justice

4. Humphrey, S. E., Nahrgang J. D., \& Morgeson F. P. (2007). Integrating motivational, social, and contextual work design features: A meta-analytic summary and theoretical extension of the work design literature. Journal of Applied Psychology (92), 1332-1356.

5. Baldwin, E. (2015). Organizational justice. Retrieved from https://www.employmentstudies.co.uk/system/files/resources/files/mp73.pdf

6. Amos, H. (2013). Meaning job satisfaction. Retrie ved from http://dictionary.university/job\%20satisf action.

7. Hulin, C. L., \& Judge, T. A. (2003). Job attitudes. In Borman, W. C., Ligen, D. R., \& Klimoski, R. J. (Eds.), Hand book of psychology: Industrial and organizational psychology, 255-276, Hoboken, NJ: Wiley.

8. Nayer, P. (2016). Essay on promotion of employees public administration. Retrieved from http://www.politicalsciencenotes.com/essay/public -administration/essay-on-promotion-ofemployees-public-administration/13673.

9. Pigors, S., \& Myers, C. (2014). Promotion of employee: it's meaning and definition explained! Retrieved from http://www.yourarticlel ibrary.com/employee management/promotion-ofemployee-its-meaning-and -definitionexplained $/ 25975$

10. Harare, J. (2008). Employee commitment importance and types. Retrieved from https://www.citehr.com/58418-employeecommitment-importance-types.html.

11. Marzullo, F. (2018). What is employee commitmen $t$ ? Retrieved from https://www.zenefits.com/blog/t he-value-of-employee-commitment/
12. Alison, D. (2018). What is a salary employee. Retr ieved from https://www.thebalancecareers.com/wh at-is-a-salary-employee-2062093.

13. Idio, I. (2008). The impact of substantial investment in education, workforce training, and the implications on school transformation and economic development in Akwa Ibom State. Educational Leadership, 65(8):32-39.

14. Ben. (2014). Quality assurance for effective agricultural teacher preparation and school administration in Nigeria. Proceedings of INTCESS14-International Conference on Education and Social Sciences Proceedings.3-5 February 2014- Istanbul, Turkey, 1706 -1712.

15. Ortyoyand, E., \& Agbe, T. (2005). Motivation and teachers 'quality in schools. Research in Art Education, 4(3):14-23.

16. Gabrielle, J. \& Hogan, L. (2013). The utilization, deployment, and management of teachers in Malawi, Botswana, South Africa and Uganda. World Journal of Education, 4(4):1-10.

17. Powers, W. J., Rabinstein, A. A., Ackerson, T., Adeoye, O. M., Bambakidis, N. C., Becker, K., ... \& Jauch, E. C. (2018). 2018 guidelines for the early management of patients with acute ischemic stroke: a guideline for healthcare professionals from the American Heart Association/American Stroke Association. stroke, 49(3), e46-e99.

18. Azman, I. H. (2011). The relationship between transformational leadership, empowerment, and organizational commitment. Business and Economics Research Journal, 2(1):89-107.

19. Abbas, M. \& Asri, G. M. (2012). The relationship between effective organizational communication and the performance of central office staff. Quarterly Publication 2(5), 1549-1554.

20. Chung-Chieh, L., \& Chih-Jen, C. (2013). The relationship between employee commitment and job attitude and its effect on service quality in the tourism industry. American Journal of Industrial and Business Management. 3(2);301-331.

21. Ademola, B. O. (2012). Effect of organizational justice and organizational environment on turnover intention of health workers in Ekiti State, Nigeria. Research in World Economy, 3(1);1-5.

22. Ryan, R. M., \& Deci, E. L. (2000). Selfdetermination theory and the facilitation of intrinsic motivation, social development, and wellbeing. American psychologist, 55(1), 68.

23. Cammann, C., Fichman, M., Jenkins, D., \& Klesh, J. (1979). The Michigan organizational assessment questionnaire. Unpublished manuscript, University of Michigan, Ann Arbor.

24. Wakil, A. A. (2015). Survey of pay satisfaction, job satisfaction and employee turnover in selected business organisations in Lagos, Nigeria. Global Journal of Social Sciences, 1(4);1-8. 